\title{
CDISC SDTM Immunogenicity Specimen Assessments Test Code Terminology
}

National Cancer Institute

\section{Source}

National Cancer Institute. CDISC SDTM Immunogenicity Specimen Assessments Test

Code Terminology. NCl Thesaurus. Code C120525.

Terminology associated with the immunogenicity specimen assessments test code codelist of the Clinical Data Interchange Standards Consortium (CDISC) Study Data Tabulation Model (SDT M). 